\title{
Poverty and marginalization in Nayarit, México: four communities of the Aguamilpa hydroelectric dam
}

\section{Pobreza y marginación: el caso de cuatro localidades de la presa hidroeléctrica Aguamilpa, en el estado de Nayarit}

HERNÁNDEZ-GUERRERO, Felipe $\dagger^{*}$, GONZÁLEZ-BERNAL, Víctor Manuel, DEL REALFLORES, Jaime H. and MARTÍNEZ-RIVERA, Juan Ildefonso

Universidad Autónoma de Nayarit. Academic Unit of Economics, Mexico.

ID $1^{\text {st }}$ Author: Felipe, Hernández-Guerrero / ORC ID: 0000-0003-3959-4160

ID $1^{\text {st }}$ Co-author: Víctor Manuel, González-Bernal / ORC ID: 0000-0002-6221-6734

ID $2^{\text {nd }}$ Co-author: Jaime H., Del Real-Flores / ORC ID: 0000-0003-4457-8421

ID $3^{\text {rd }}$ Co-author: Juan Ildefonso, Martínez-Rivera / ORC ID: 0000-0001-9983-1768

DOI: $10.35429 / J M P C .2020 .17 .6 .17 .34$

Received January 15, 2020; Accepted June 30, 2020

\begin{abstract}
The research work that is presented, aims to carry out an analysis of the living conditions that prevail in the population, of four marginalized rural communities located in the banks of the Rio Grande de Santiago, in the State of Nayarit. In addition to analyzing the implications of social policy to reduce poverty and marginalization, phenomena closely related to social deprivation. Each approach and methodology used for its analysis, have shed light on the different studies on social deprivation that lead individuals or groups to suffer this situation. In the study that is presented, it is observed, that the construction of the PHA and the social programs implemented by the government at its different levels, have not been sufficient to solve the problems of extreme poverty in which the population of marginalized rural localities is found. In the same way, it is concluded that it is necessary to advance towards the articulation of concepts and ways of measuring poverty and marginalization, as well as, on the ways of evaluating, social policies, with the understanding that the interventions of the three orders of government, will be more effective as long as they achieve a multidimensional approach that prioritizes the human being.
\end{abstract}

Poverty, Marginalization, Politics social

\begin{abstract}
Resumen
El trabajo de investigación que se presenta, tiene como objetivo realizar un análisis de las condiciones de vida que prevalecen en la población, de cuatro comunidades rurales marginadas, ubicadas en las Riberas del Rio Grande de Santiago, en el Estado de Nayarit. Además, analiza las implicaciones de la política social, para reducir la pobreza y marginación, fenómenos relacionados a las carencias sociales. Cada enfoque y metodología empleados en las investigaciones realizadas, han permitido importantes aportaciones al conocimiento sobre la pobreza y las privaciones sociales de las personas o grupos que se encuentran en esta condición. En el estudio que se presenta, se observa, que la construcción de la PHA y los programas sociales implementados por el gobierno en sus distintos niveles, no han sido suficientes para resolver los problemas de pobreza extrema en que se encuentra la población de las localidades rurales marginadas. De igual manera, se concluye que, es necesario avanzar hacia la articulación de conceptos y formas de medición de pobreza y marginación, así como, sobre las formas de evaluar políticas sociales; en el entendido de que las intervenciones de los tres órdenes gobierno, serán más efectivas, en tanto logren un abordaje multidimensional, que priorice el ser humano.
\end{abstract}

Pobreza, Marginación, Política social

Citation: HERNÁNDEZ-GUERRERO, Felipe, GONZÁLEZ-BERNAL, Víctor Manuel, DEL REAL-FLORES, Jaime H. and MARTÍNEZ-RIVERA, Juan Ildefonso. Poverty and marginalization in Nayarit: four communities of the Aguamilpa hydroelectric dam. Journal of Microfinance Planning and Control. 2020. 6-17:17-34.

\footnotetext{
* Correspondence to the Author (Email: fhernad@uan.edu-mx)

$\dagger$ Researcher contributing as first author.
} 


\section{Introduction}

In September 2000, Mexico signed the agreements made at The Millennium Summit, together with 198 countries of the United Nations (UN), in the Declaration it was proposed as one of the first Millennium Goals (MDG), "Eradicate extreme poverty and hunger", because there are different areas of the world where the population lives in conditions of extreme poverty and marginalization, and the deadline for its achievement was set in 2015.

However, 15 years later, at the United Nations meeting, after evaluating the results, and highlighting important achievements in reducing the phenomenon of poverty, it was found that, even when social programs have been developed and implemented to reduce this situation of poverty and social backwardness is maintained, in a large number of communities around the world, to the extent that, when considering the Sustainable Development Goals (SDG), the first of them turned out to be, "End poverty" and the second, "Zero hunger", consequently, the question arises, what is the reason why the expected results have not been achieved? The General objective is to evaluate the impact of the construction of the Aguamilpa Hydroelectric Dam (PHA) and of the social programs, on the living conditions of the population, in four marginalized rural communities living in poverty in the state of Nayarit.

Consequently, it has as Specific objectives.

1st. Give an account of the economic situation that permeates the population of the localities under study after 26 years of the construction of the PHA.

2nd. Identify the changes that have occurred in the life of the population under study, as a result of the construction of the PHA and the implementation of social programs to support marginalized and poor communities.

3rd. Carry out a field investigation in the localities under study, supported by interview and survey techniques, in order for students of the Political Science academic program to get involved in the research and learn about the population's perception of changes in the living conditions that led to the construction of the PHA.
The hypothesis proposed in this work establishes that, with the construction of the Aguamilpa Hydroelectric Dam and the social programs implemented by the government at its different levels, they have not been sufficient to resolve the conditions of poverty and social backwardness in which the population of marginalized rural localities, located in the PHA region.

What has been stated in the previous paragraphs, motivated those of us who make up The Academic Body of "Economy, Public Policies and Human Rights", to work in the elaboration of the project: Local development and public policies to safeguard the rights of the riverside peoples of the state of Nayarit; and in whose research process, direct observation, survey and interviews with residents of four rural and marginalized localities of the PHA region were used.

The field work carried out allowed us to obtain first-hand information from the inhabitants, and in turn, to know and analyze the poverty conditions of the population that lives on the margins of the P.H.A basin; as well as dimensioning the impact of the existence of the dam in question, 26 years after its construction, to finally proceed to evaluate the results of the social programs that the state has carried out in marginalized localities, to reduce poverty.

Consequently, the document presented was prepared based on the data collected and the information obtained through the survey and is complemented by the opinions expressed in interviews with some key residents of the communities, mainly community authorities and seniors.

The work is made up of four sections. In the first one, a conceptual theoretical framework is incorporated, where different concepts of poverty and marginalization are analyzed; later, in the second point, a description corresponding to the territory and the localities under study is presented; It continues in the third section, with the methodology and techniques used for the development of the research; to continue, in the fourth section, with the development of the research, where a comparative descriptive analysis of the situation of the localities is presented, taking into account the data collected; finally, the conclusions and recommendations resulting from the work are made available. 


\section{Conceptual framework}

\section{Poverty}

The issue of poverty has been addressed by researchers from different disciplines and approaches, by national and international organizations, as well as by governments of different levels and countries. In the same way, as it is a polysemic concept, with different scopes and interpretations, as pointed out by Spicker (2003), poverty has been the subject of strong debates and analysis, from different perspectives and methodologies, thus generating a large quantity and a variety of descriptive, narrative, analytical, and quantitative studies.

Bazán, Quintero, and Hernández (2011), in their work, evolution of the concept of poverty and the multidimensional approach, make an analysis of the concept of poverty, from the 20th century to the present, and explain how, over time, it has this conception has been changed.

The World Bank highlights that poverty was originally understood as a statistical data that can be compared, and that has as a measurement factor, the impact on the per capita income of the countries, classifying them according to a higher or lower income.

Between the years 1960 and 1970, the approach to the analysis of poverty emerged, supported by basic needs, which provides a multidimensional framework for the development of public policies, however, one of the failures was that this approach It did not rely on an explicit regulatory framework; rather, it was simply used as a substitute for the approach focused on income data, in addition to not evaluating the conditions of the population spaces.

Beginning in the 80 's of the last century, the concept of poverty began to develop, addressing not only the lack of monetary and material resources, but also, considering the deficiencies in education, health, housing, security and freedom.
Some of the scholars of the subject, champion this position, affirming that the condition of poverty is not limited to a dimension such as income; Rather, it manifests itself in all dimensions of human life, such as housing, education and health (Deleeck et al., 1992).

In this same decade, the Economic Commission for Latin America and the Caribbean (ECLAC); raises a concept of poverty supported by a new approach, that of unsatisfied basic needs, which had its application, mainly in Latin America.

Those who assumed the ECLAC approach resorted to data from the population and housing censuses, seeking to ascertain whether or not households met their main needs. For this, their studies would have to cover four phases: 1. Determine the group of minimum needs, which can be studied with information from the census; 2 . Select census indicators that represent said needs; 3 . Define the critical level of satisfaction, for each need; 4. Ensure that the selected indicators correspond to situations of poverty (Quintana, 2008).

In the 90's, of the 20th century, the World Bank incorporated a definition of poverty, which is identified with the impossibility of reaching a minimum standard of living in health services, drinking water and education. In addition, any financial limitation that prevents you from enjoying a satisfactory life.

Another contribution to the issue of poverty is the one presented by Amartya Sen (1992), who indicates that this concept is built from the absence of capacities that allow any individual to insert themselves into society, through the exercise of their will, that is, of what people can and want to do, and stresses that poverty is not a matter of poor well-being, but of an inability to achieve well-being, precisely due to the lack of means. 
He adds that there are geographical, biological and social factors that multiply or diminish the impact of income on each individual. In addition to the fact that, among the most disadvantaged, there are generally absent elements, such as education, access to land, health and longevity, justice, family and community support, credit and other productive resources, the same is true, in the case of voice, in institutions and in access to opportunities. (IDB, 2001).

Peter Townsend (1993: 446), another of the scholars of the phenomenon of poverty, defines it as, "the situation in which those live, whose resources do not allow them to meet the social demands and customs assigned to citizens, in a given temporal-spatial coordinate "; and highlights that, in addition to food, health, education and housing, at present, there are social needs, access to the Internet, cell phones, and being able to vacation at least once a year, among others.

The United Nations Development Program (UNDP, 1997) defines poverty as the denial of options and opportunities to live a tolerable life. Therefore, anyone who works is poor and their income is insufficient to enjoy a satisfactory life, and that, in addition, when setting future goals, their economic capacity prevents them from projecting achievable goals for a better quality of life.

For his part, Paul Spicker (sf: 151) identifies eleven possible parameters to distinguish poverty: need, standard of living, insufficient resources, lack of basic security, lack of entitlements, multiple deprivation, exclusion, inequality, class, dependence and unacceptable suffering. These aspects can be mutually exclusive or apply all at the same time. It can be seen that Spicker's work contributes elements to establish different types of poverty, and contemplates the psychological and social spheres, by pointing out that he does not cover basic human needs, such as decent housing, balanced food, clothing and education; it causes discrimination and, consequently, affects the psychological state of individuals. He closes by stating that people can be considered poor, for the simple fact that they are at a disadvantage compared to others in society.
O'Higgins and Jenkins (1990) point out that economically developed countries have focused on determining the level of income, which allows reaching a minimum acceptable standard of living in society and at the time they live, with which, the existence of a close relationship between poverty and inequality is accepted; since the latter would lead to the manifestation of poverty conditions in the population, even though it does not necessarily mean that poverty will always be present, when there is inequality; which will only happen if the inequality gap is so wide that it is located beyond the "critical level" (cited in Spicker, Álvarez and Gordon, nd: 295-296).

However, O'Higgins and Jenkins emphasize that this approach suffers from important limitations, since, by defining poverty in these terms, it would have the consequence that an eventual reduction of the resources of the richest would be equivalent to a reduction in poverty, which is not necessarily the case. (Ibid.) In Mexico, government institutions, such as the Ministry of Social Development (SEDESOL, 2002), through its Technical Committee, state that poverty is a term that defines "the deprivation of the elements necessary for human life, within a society, and of means or resources, to modify this situation ". Consequently, any person who lives in this condition, and who faces a difficult economic situation day by day, will feel alienated and their situation will worsen.

The National Population Council of Mexico (CONAPO, 2000), for its part, defines poverty as "a structural phenomenon that originates in the mode, style or historical pattern of development, which is expressed, on the one hand, in the difficulty of spreading technical progress throughout the productive structure and in the country's regions; and on the other, in the exclusion of social groups, of the development process and of the enjoyment of its benefits".

In the case of Mexico, it is important to note that, in relation to the measurement of poverty, the National Council for the Evaluation of Social Policy (CONEVAL, 2018), has a multidimensional methodology, which it applies to measure the achievement of the objectives of social development programs and policies; Through which, it monitors the level of poverty and establishes thresholds or lines of poverty and unsatisfied needs, which, when exceeded, lead to the identification of people living in poverty. 
The CONEVAL determines that a person is in a situation of poverty, when they have at least one social deprivation, out of six identified as poverty indicators: educational backwardness; access to health services; access to social security; quality and spaces of the house, basic services in the house; access to food and social cohesion; Furthermore, their income is insufficient to purchase the goods and services they require to satisfy their food and non-food needs. But if you have 3 or more social deprivations, in addition to insufficient income to purchase the basic food basket, you are considered in a situation of extreme poverty.

Regarding poverty, ECLAC (2003) affirms that this is a complex social and economic phenomenon, with multiple facets and causes, which include deprivations in the aspects of individual and collective well-being. And it is suggested that, if an individual has deprivations; lack of employment, health problems, unworthy housing, poor diet, etc., that is, if their individual well-being is affected, it will be difficult to overcome and achieve collective goals that improve their quality of life.

To close with the concept of poverty, we cite Gordón (2004: 51), who defined as poor, those people, families or groups of people, "whose resources are so limited that they translate into minimally exclusion from the standard of living, acceptable in the member state in which they live" and emphasizes that poverty is a multidimensional problem that affects humanity, and that the social relationship that exists between men tends to oppress one another, the latter being, who suffer its consequences.

\section{Marginalization}

The UN, through the United Nations Development Program (UNDP), has developed a methodology to measure the degree of Marginalization of territorial units, based on a Human Development Index (HDI), which incorporates indicators improvement in the living conditions of the population, related to the increase in assets with which they can cover their basic and complementary needs; and, with the creation of an environment in which human rights are respected. Among these indicators, education, life expectancy at birth and GDP per capita stand out.
The National Population Council (1990) defines marginalization as a structural process, related to the socioeconomic development achieved by our country, and that hinders the propagation of progress to all social groups, which affects the productive structure and is expressed in territorial inequalities.

Regarding the measurement of the marginalization index, the CoNaPo incorporates a set of indicators and variables, which allow locating localities according to their degrees of marginalization on the map of the country, which it classifies as: very low, low, medium, high and very high (CoNaPo / Progresa, 1998: 58).

The concept of marginalization, established by CoNaPo, is objectified in localities and municipalities, through the dimensions; education, housing and monetary income. While at the state level and, with the intention of accounting for differential access to the enjoyment of development benefits, the dispersion of localities is added; the measurement focuses on the deficiencies of the population and, on access to basic goods and services, considering its three dimensions.

Marginalization is seen as a phenomenon that affects localities, and consequently, the people who live in them. However, you can find a highly marginalized locality, and some of its inhabitants may be literate, live in houses with piped water, electricity, a firm floor, low overcrowding and earn a sufficient income to not be considered poor (CoNaPo / Progresa, 1998: 58).

On the other hand, and in relation to indigenous peoples, the United Nations (UN) estimates that in the world there are at least 300 million people who are indigenous, and they belong to around 5,000 groups, distributed in more than 70 countries; and it is emphasized that it is not correct to assert that all the people who belong to these indigenous groups are poor. However, it can be argued and evidenced that, in the various social contexts in which indigenous peoples find themselves, they are more likely to be poor than non-indigenous peoples. (UN, 2002). 
For its part, the World Health Organization (WHO) presents data on indigenous peoples, in which it highlights that, in terms of health, life expectancy at birth for these groups is between 10 and 20 years less, than the rest of the population; and infant mortality is 1.5 to 3 times higher than the population average; The same occurs in the case of malnutrition, malaria, dengue, cholera and tuberculosis, diseases that affect these groups to a greater extent (WHO, 1994).

Psacharopoulos and Patrinos (1994) observe that, for indigenous peoples, these patterns of disadvantage mentioned above are found in both developed and undeveloped countries, without showing signs of improvement over time.

This position of the aforementioned authors coincides with that of the United Nations High Commissioner for Refugees, UNHCR, by stating that it is a reality that discrimination against indigenous peoples has been institutionalized in many countries and, in addition, raises the existence of documentation on problems associated with the administration of justice, access to social security and health of indigenous peoples (cited in Cimadamore, Eversole, and McNeish, 2003).

However, institutional methodologies have led to the implementation of public actions aimed at reducing the problems of poverty, marginalization, social backwardness, social exclusion and inequalities; Likewise, they have inspired scholars of social policies to make their contributions from a critical analytical perspective, while contributing to the conceptualization and measurement of poverty and marginalization.

It should be noted that, among the measurement instruments currently used by the Mexican government, are; the marginalization index and the poverty index from a multidimensional perspective, used by CONEVAL, which are complementary to each other: the first, emphasizes the territorial issue, the population living in marginalized localities; while the second establishes thresholds (poverty lines and social deprivation) that, when exceeded, identify people in a condition of poverty.
However, considering that, in native peoples, it is where marginalization and poverty are most reflected, it is necessary to consider the perception of these phenomena, from their territory, from the local; since, for its inhabitants, it is in these conditions, in which the continuity of their culture, their values, and their ways of life and coexistence is maintained. Aspect with which, is agreed by those who participated in the development of the project, and that gave the guideline for the realization of the document that is presented.

\section{The Territory: The Aguamilpa Hydroelectric Dam}

Taking into account what is embodied in the Political Constitution of the United Mexican States, on equality, freedom, security, property and social guarantees before the law in its different articles referring to the rights of native peoples, in Mexico, for several decades, they have been implemented policies and social programs to support the most vulnerable groups and communities, seeking with them to reduce the problems of education, health, food, material poverty, communication, electricity, piped water, among others (Morret, 2001, cited in Hernández et al., 2018)

It should be noted that, before the construction of the Aguamilpa hydroelectric dam, the communities under study, due to their high degree of marginalization, manifested conditions of poverty, identified with a series of deficiencies: communication routes, access to healthy food, water piped, health services, education, quality of housing, employment, among others; Some of them, closely interrelated, as is the case of the absence of communication channels, which prevented the assistance to the Nayarit capital (Tepic), to buy its consumer goods, to have medical attention, to have sources of employment, etc., and that also prevented the arrival of the benefits of the social programs implemented by the federal and local governments. 
This prevailing situation manifested some important changes from the construction of the Hydroelectric Dam in Nayarit, since it can be observed that the residents of the riverside communities had permanent employment and monetary income, at least while its construction lasted; Likewise, there were transformations in the communities, since their access roads "modernized" them, which led to better communication between them; processes of social interculturality took place; food assurance; although as a counterpart, crime, abuse, and rapes proliferated (CDI, 2012 and Gómez 2008, cited in Hernández et al., 2017).

With the relocation of the localities under study as a result of the construction of the Aguamilpa Dam, it is observed that; Even though there was a temporary benefit, by compensating them economically for their flooded lands and building new homes for them, it substantially modified their eating habits and the destination of the product of their productive activities.

Since the localities under study, prior to the construction of the dam, were essentially dedicated to fishing and agriculture, allocating their product to their own and family consumption; It should be noted that, in the case of agriculture, which is currently seasonal, it continues to be mainly oriented to the production of corn, its destination being self-consumption.

However, it is not the same case of fishing, an activity for which exploitation projects are carried out, which facilitated the formation of the Union of Fishermen and the Cooperative Fisheries and Aquaculture Society, which manages 206 permits of fishermen and 400 suppliers, in addition to increasing the production and exploitation of fishing by the inhabitants of the localities of the region, their destination markets being other states of the country such as Mexico, Puebla and Guerrero, as indicated by Aranda when making his study on the Ejido of Colorado de la Mora Aranda (2020) After the construction of the hydroelectric dam, the social policy implemented by the three levels of government has focused on providing the towns in question, in a rationed manner, with basic services: health, electricity, education, support for housing, among others; which has been used as the flag of professional politicians, to gain access to power, through the vote of citizens.
This can be observed in the results of CONEVAL, a governmental body empowered to establish the guidelines and criteria of social policy, which show from their evaluations that, from 1990 to date, the municipalities of the mountainous area of Nayarit have manifested higher levels of extreme poverty.

\section{Description of the locations}

The general information of the four localities was obtained from internet pages, in various official and private sources, always seeking that the data were corresponding and homogeneous. Aguamilpa, is a rural town that belongs to and is located in the Municipality of, Del Nayar, in the State of Nayarit, and according to the last data reported, in 2010, it had a population of 215 inhabitants, of which which, 100 were male and 115 female. Of the total population, $13.02 \%$ could not read or write.

Of the 36 homes that existed in the town, 97\% did not have piped water, no home had a toilet and, in addition, had no connection to drainage, only $25 \%$ had electricity, and $22.8 \%$ of the homes had with dirt floor. Regarding the possession of electrical devices, $38.9 \%$ had radio and $11 \%$ had television.

Potrero de la Palmita, like Aguamilpa, belongs to the municipality of, Del Nayar, for the year in question 2010, it had a total of 432 inhabitants: of them 213 were male and 219 female. Of the people who live in the town, 70 of them could not read or write, which represented $15.97 \%$ of the total.

Of the 86 homes that exist in the town, $55.8 \%$ lacked piped water, $56 \%$ lacked toilets, $72 \%$ lacked drainage, $46 \%$ of the houses lacked electricity, and $26.7 \%$ they have their dirt floor. Regarding electrical appliances, 51.2\% have radio and only $18.6 \%$ have television.

Colorado de la Mora, like the previous ones, is a marginalized rural town, which belongs to the municipality of Tepic, state of Nayarit. It has a total of 331 inhabitants, of them, 161 are male and 170 female, and it is noteworthy that, of the total population, $18.13 \%$ is illiterate. 
In 2010, there were a total of 75 homes in the town, of which $44 \%$ lacked piped water, $28 \%$ did not have a toilet and $14 \%$ suffered from a lack of drainage, $58.6 \%$ did not have electricity, while $10.6 \%$ had dirt floors in their homes. While, speaking of electrical appliances, $58.67 \%$ of the homes had a radio and $14.67 \%$ had television.

Finally, Zapote de Picachos, is also a marginal rural town belonging to the municipality of Tepic, which, in 2010, was inhabited by 439 inhabitants, of which 204 were male and 235 female; Of the total population $42.6 \%$, that is, 86 people are considered illiterate, because they cannot read and write.

The town is made up of 91 homes, of these, $25.8 \%$ lacked piped water, $92.3 \%$ had no toilet, and $47.3 \%$ of the homes were without drainage, $74.7 \%$ of the homes had no electricity, $49.5 \%$ were homes with dirt floors and, only in $15.4 \%$, that is, 14 households have television.

As can be seen, the average illiteracy in the four localities reaches $22.43 \%$, which is quite delicate, due to all the implications it has. Such as being able to carry out the minimum operations for the collection or payment of salaries or merchandise bought and / or sold, the possibility of having job opportunities in other types of activities, reading or writing minutes and health recommendations, etc.

The housing conditions and the situation of marginalization and social backwardness for the communities are presented in a concentrated way in Table 1.

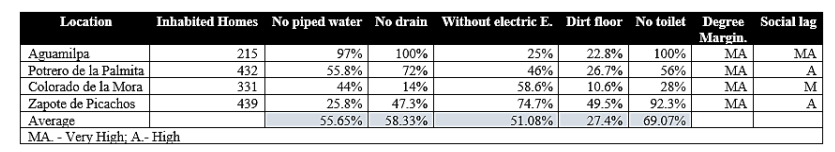

Table 1 Rural towns in the state of Nayarit: Social deficiencies, degree of marginalization and social backwardness 2010

Source: Prepared with information from SEDESOL. DEPUTY DIRECTORATE GENERAL FOR MICROREGIONAL PLANNING

Microregiones Unit Recovered http://www.microrregiones. gob.mx/catloc/contente.aspx? refnac $=180170225$

\section{Methodology to be developed}

In this research work, an analysis is carried out of the living conditions that prevail among the inhabitants of four rural localities of the State of Nayarit, which are located in the Aguamilpa Hydroelectric Dam (PHA) region, and in turn, they are classified by the Institute for Social Development (INDESOL) as highly marginalized.

In the work, the living conditions that prevail in the four locations under study are described, prioritizing the use of field research and ethnographic techniques, which allow to know directly, the living conditions that prevail in the population of These inhabit the four mentioned localities under study: Colorado de la Mora and Zapote de Picachos, which are part of the municipality of Tepic; as well as Potrero de la Palmita and Aguamilpa, which correspond to the municipality of Del Nayar.

The Hydroelectric Dam in question, was put into operation in September 1994, is located in the channel of the Rio Grande, Santiago, in the municipality of Tepic, Nayarit; and corresponds to the hydrological basin of the Lerma-SantiagoChapala runoff.

The reason that leads us to focus on these localities is that when the PHA was built, they underwent radical changes in the living conditions of their inhabitants; being two of them, relocated, one of them, Potrero de la Palmita, from the Municipality of Del Nayar, and the other, Colorado de la Mora, from the Municipality of Tepic, in addition, one more town from each municipality was incorporated into the study, which had not suffered relocations.

The aforementioned allowed us to carry out an analysis in the communities, from a double perspective: from the impact of the Hydroelectric Dam and, from the social care policies implemented by the Government at its different levels. 
Once the communities under study had been identified, the sample size was determined, which according to its open population, should be 303 people, according to the calculation made through the surveymonkey procedure, but as the priority criterion for the survey, is the opinion about their living conditions, before and after the construction of the dam, to be surveyed, they should be of origin and be over 45 years old, which led to a total survey of 85 people in the four localities.

Given the complexity of access and connection with the population of the study locations, the support of the Coordination of Indigenous Peoples (CDI) was used, which also made it possible to be present at community meetings, which are held every month. carried out in each community, and in turn, request permission and support to carry out the survey, with people of the indicated ages, since they are the ones who have observed the changes that these localities have undergone.

Subsequently, a questionnaire was applied by the team of teachers and students of the Political Science Academic Program, along with others, they carried out a series of interviews with the leaders and authorities of the corresponding communities.

The 85 questionnaires applied were distributed as follows; eight in Aguamilpa, 21 in Potrero de la palmita, 25 in Zapote de Picachos, and 31 in Colorado de la mora.

The results obtained are presented considering the dimensions stipulated in the questionnaire: demographic, economic, education, quality of housing, and food; in the same way, the perception of those surveyed is observed, regarding their situation before and after the construction of the hydroelectric dam.

To process the information captured through the survey, descriptive statistics were used, which allowed the results to be processed, the graphs elaborated, and the averages obtained, to facilitate the corresponding analysis.
In addition to the above, secondary sources were reviewed to complement and reinforce the information related to sociodemographic data. On the other hand, specialized magazines, articles and books on the subject of poverty and marginalization were reviewed.

It should be noted that the work presented is aimed at the analysis of four rural and marginalized localities of the state of Nayarit, and the concept of poverty will be approached from two perspectives: one, onedimensional, in which the idea of incorporating to all those people who are below the income that is considered necessary to cover basic needs; and the other, multidimensional, where they are considered, the lack of access to health services; social Security; communication infrastructure; public services in the house, such as water, drainage, electricity; the precariousness of housing conditions, such as type of floor, walls, ceiling, according to its climatic conditions; and, the lack of a balanced diet.

Both perspectives address the human rights stipulated in the political constitution of the United Mexican States, and are closely related to quality of life. In addition to the fact that these dimensions are important for the study of problems related to poverty and marginalization of native peoples, because they have to do with the lack of opportunities for an individual or family to have sufficient resources and meet your basic needs.

\section{Development of research carried out in rural localities in the state of Nayarit}

The field research process was carried out at the end of November 2017 and at the beginning of 2018 , firstly, the towns of the municipality of Tepic Nayarit were assisted; Colorado de la Mora and Zapote de Picachos, subsequently, the towns of the municipality of, Del Nayar; Aguamilpa and Potrero de la Palmita.

During the stay in the four localities, a questionnaire was applied to a total of 85 people, who, as mentioned above, sought to have an age greater than 45 years, in the same way, an interview was conducted with the judges of the communities, Aguamilpa and Zapote de Picachos. 
Likewise, an appointment was previously agreed, together with personnel from the Coordination for the Development of Indigenous Peoples (CDI), to participate in the meeting that is held every month in the communities, in order to discuss community affairs, and seek joint solutions.

To achieve better results in the survey, they learned about the activities carried out by the University, its teachers and students in the training process, as well as the possibilities and requirements and support for entry, of the young people of these indigenous peoples, to the University. Once the authorization of the community assembly was obtained, the information was collected, with the respondents kindly agreeing to answer the questions that were asked, which yielded the results that are presented below.

\section{Concentration of the information captured through the consultation instrument according to its size}

\section{Demographic dimension}

According to the information provided by the people surveyed, in the 4 rural locations visited, it was found that, in the total of these people's homes, there are 377 people, and there is an average of 4.79 people per home, see Table 2 .

The distribution of the population, according to their sex, is almost equal, since 187 (49.60\%) of them belong to the female sex and $190(50.40 \%)$ to the male sex.

\begin{tabular}{|l|r|r|r|}
\hline \multicolumn{1}{|c|}{ Location } & \multicolumn{1}{c|}{$\begin{array}{c}\text { Interviewed } \\
\text { people }\end{array}$} & $\begin{array}{c}\text { People } \\
\text { in } \\
\text { homes }\end{array}$ & $\begin{array}{c}\text { Average } \\
\text { per } \\
\text { home }\end{array}$ \\
\hline Aguamilpa & 8 & 41 & 5.8 \\
\hline Potrero de la Palmita & 31 & 139 & 4.8 \\
\hline Colorado de la Mora & 25 & 108 & 4.3 \\
\hline Picacho sapote & 21 & 89 & 4.2 \\
\hline Total & $\mathbf{8 5}$ & $\mathbf{3 7 7}$ & $\mathbf{4 . 7 9}$ \\
\hline
\end{tabular}

Table 2 Dwellings and distribution of people by locality under study

Source: Own elaboration based on the data of the applied survey

\section{Economic dimension: salary and employment.}

When identifying the people who work, it was found that 39 of the 187 women, or $21 \%$ of the total, work or help in productive activities outside the home, and of the 190 men counted, it was observed that 115 of them, work in productive activities, which represent $61 \%$ of the total (see Table 3). It is noteworthy that, according to what was expressed by the interviewees, a large part of the male inhabitants moves to the interior of the state during periods of agricultural harvests, including, on occasions, entire families.

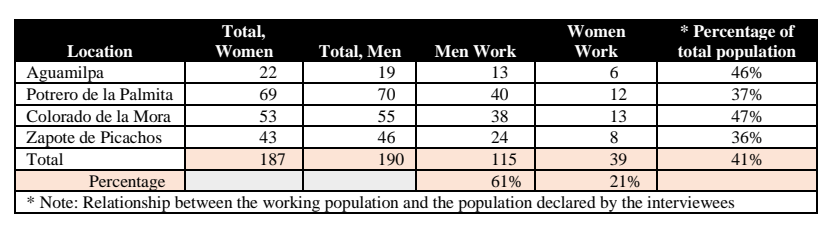

Table 3 Distribution of the population by sex and people who work in the localities under study

Source: Own elaboration based on the data of the applied survey

When analyzing the salary received by people who work and taking into consideration the salary ranges proposed in the applied questionnaire, it is found that, of the 85 respondents, $56 \%$ received as salary, between 400 and 2000 pesos per month, while that $34 \%$ managed to obtain salaries between 2001 and 4000 pesos, $4 \%$ said they reached to obtain income between 4001 and 6000 pesos and, 6\% of the total, indicated working without receiving salaries, see Table 4.

\begin{tabular}{|r|r|r|r|}
\hline Wage level & $\begin{array}{c}\text { Monthly Salary } \\
\text { Range }\end{array}$ & $\begin{array}{c}\text { Number of } \\
\text { people }\end{array}$ & $\begin{array}{c}\text { Percentage of } \\
\text { total }\end{array}$ \\
\hline $\mathrm{a}$ & 400 to 2000 & 48 & $56 \%$ \\
\hline $\mathrm{b}$ & 2001 to 4000 & 29 & $34 \%$ \\
\hline $\mathrm{c}$ & 4001 to 6000 & 3 & $04 \%$ \\
\hline $\mathrm{d}$ & No recibe & 5 & $06 \%$ \\
\hline Total & & 85 & $100 \%$ \\
\hline
\end{tabular}

Table 4 People according to range of salary received in the 4 towns under study

Source: Own elaboration based on the data of the applied survey 


\section{Education dimension}

When considering this dimension, and according to the response provided by the respondents, in relation to the question about the years of study that they have carried out, at the time of the application of the questionnaire, it can be observed that, the highest percentage of the answers given, $42.35 \%$, is concentrated in people who lack studies or have no year of studies covered.

According to the answers provided by the respondents, if one considers the people who have not completed the primary level of education, that is, the six years that correspond to that level, in Table 5, the high percentage of people can be observed $(61.18 \%)$ who are in this situation, while, at the primary level, it has only been completed by $15.29 \%$ of the people, while the secondary level has been completed by $14.12 \%$, of the respondents and, the higher or higher technical level, only two people have done it $(2.3 \%)$.

\begin{tabular}{|c|c|c|c|}
\hline $\begin{array}{l}\text { Years of } \\
\text { study }\end{array}$ & People & Percentage & \\
\hline 0 & 36 & $42.35 \%$ & \\
\hline 1 & 5 & $05.88 \%$ & \\
\hline 2 & 3 & $03.53 \%$ & \\
\hline 3 & 3 & $03.53 \%$ & \\
\hline 4 & 4 & $04.71 \%$ & \\
\hline 5 & 1 & $01.18 \%$ & $61.18 \%$ \\
\hline 6 & 13 & $15.29 \%$ & \\
\hline 8 & 4 & $04.71 \%$ & \\
\hline 9 & 12 & $14.12 \%$ & \\
\hline 15 & 1 & $01.18 \%$ & \\
\hline 16 & 2 & $02.35 \%$ & \\
\hline \multirow[t]{2}{*}{ N.C. } & 1 & $01.18 \%$ & \\
\hline & 85 & & \\
\hline
\end{tabular}

Table 5 Literacy in the study areas

Source: Own elaboration with data from the survey

\section{Housing quality dimension}

When transferring the analysis to the housing conditions, from the point of view of the material used in its construction, $83.9 \%$ of the surveyed population indicated that they have built the roof of their houses made of sheets, meanwhile, $8.9 \%$ answered that they built it from cement, while $12.5 \%$ stated that they built it from another material, in which tiles predominate.
Regarding the material used for the construction of the floor of their homes, $66.7 \%$ indicated that they were built of cement, $28.3 \%$ highlighted that the floor of their houses is made of earth, $3.3 \%$ they built it of mosaic and, $1.7 \%$ of other material.

Regarding the material of the walls of their houses, $63.3 \%$, of the people surveyed, answered that their house is built of adobe, $21.7 \%$ of them, highlighted that the walls in their home are made of brick or block, $13.3 \%$ responded that, in their house, the walls are made of wood, and $1.7 \%$, a person, has their house with cardboard walls, see Table 6 .

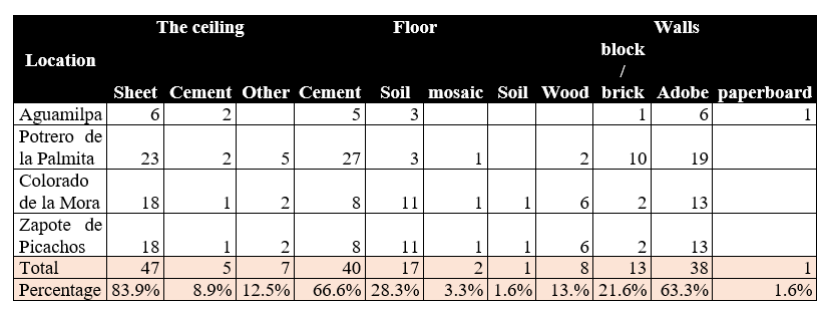

Table 6 Construction material in the homes of the towns under study

Source: Own elaboration with survey data

\section{Health and well-being dimension: provision of water and food}

When asked about the origin of drinking water, $71 \%$ of the people surveyed highlighted that they obtain it from the faucet, which is the one in common use, the same one they use for other needs in which this vital liquid is required, $12 \%$ indicated that they resort to a spring to acquire their drinking water, 7\% declared that they drink water from the well, for their part, 7\% responded, consume bottled water, while $1 \%$ that is a person, water tank intake, see Table 7.

\begin{tabular}{|l|r|r|r|r|r|}
\hline \multicolumn{7}{|c}{ Localities } & \multicolumn{1}{c}{$\begin{array}{c}\text { Water } \\
\text { well }\end{array}$} & \multicolumn{1}{c|}{ Spring } & Bottled & Tank \\
\hline Aguamilpa & 6 & 1 & 1 & & \\
\hline $\begin{array}{l}\text { Potrero de } \\
\text { la Palmita }\end{array}$ & 25 & 4 & & 2 & \\
\hline $\begin{array}{l}\text { Colorado de } \\
\text { la Mora }\end{array}$ & 11 & 3 & 6 & 4 & 1 \\
\hline $\begin{array}{l}\text { Zapote de } \\
\text { Picachos }\end{array}$ & 18 & 2 & 1 & & \\
\hline Total & 60 & 10 & 8 & 6 & 1 \\
\hline Porcentaje & $71 \%$ & $12 \%$ & $9 \%$ & $7 \%$ & $1 \%$ \\
\hline
\end{tabular}

Table 7 Origin of drinking water in the towns under study Source: Own elaboration with data from the survey

Regarding the question, on the number of meals, that the people surveyed eat per day, $29 \%$ of them answered that they receive their food twice a day, while $71 \%$ highlighted that they eat their three meals a day, see Table 8.

HERNÁNDEZ-GUERRERO, Felipe, GONZÁLEZ-BERNAL, Víctor Manuel, DEL REAL-FLORES, Jaime H. and MARTÍNEZ-RIVERA, Juan Ildefonso. Poverty and marginalization in Nayarit: four communities of the Aguamilpa hydroelectric dam. Journal of Microfinance Planning and Control. 2020 


\begin{tabular}{|l|r|r|}
\hline \multicolumn{1}{|c|}{ Location } & \multicolumn{1}{c}{$\begin{array}{c}\text { People who } \\
\text { eat 2 meals a } \\
\text { day }\end{array}$} & $\begin{array}{c}\text { People who eat } \\
\text { 3 meals a day }\end{array}$ \\
\hline Aguamilpa & 4 & 4 \\
\hline $\begin{array}{l}\text { Potrero de la } \\
\text { Palmita }\end{array}$ & 10 & 21 \\
\hline $\begin{array}{l}\text { Colorado de la } \\
\text { Mora }\end{array}$ & 6 & 19 \\
\hline $\begin{array}{l}\text { Zapote de } \\
\text { Picachos }\end{array}$ & 5 & 16 \\
\hline Total & 25 & 60 \\
\hline Porcentaje & $29 \%$ & $71 \%$ \\
\hline
\end{tabular}

Table 8 Meals per day given by the people surveyed Source: Own elaboration with data from the survey

\section{Food disposition and food quality}

When considering the menu of their meals, to identify the variety and nutritional contribution of their foods, it was observed that $76 \%$, of the 85 respondents, said they consume fish more frequently, $71 \%$ of them responded that they consumed beans in different preparations, vegetables are consumed by $19 \%$ of the people, while $6 \%$ of the total consumes meat, in addition, $8 \%$ consume canned foods and, $18 \%$ of the people, answered that they consume other foods of the region, such as rice, iguanas, rabbits, etc., see Table 9.

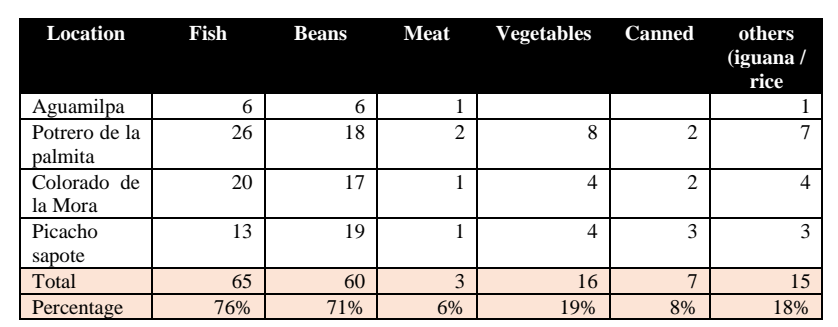

Table 9 Food variety by the people surveyed in the localities under study

Source: Own elaboration with data from the survey

\section{Perception of life before and after the construction of the Aguamilpa dam}

Finally, when questioning them about their perception, regarding the living situation that prevails in their locality, after the construction of the hydroelectric dam, in relation to the one previously had, $80 \%$ of the total of the 85 respondents, consider that the situation is much better than before, for having electricity, piped water, work and income for periods of at least 6 months a year. On the contrary, $20 \%$ of the people answered that they did not perceive improvement, compared to the condition in which they lived before the construction of the dam, so they assured that the conditions were the same as before, see Table 10 .

\begin{tabular}{|c|c|c|}
\hline Location & $\begin{array}{l}\text { Perception of } \\
\text { improvement }\end{array}$ & $\begin{array}{l}\text { Perception did not } \\
\text { improve }\end{array}$ \\
\hline Aguamilpa & 7 & 1 \\
\hline $\begin{array}{l}\text { Potrero de la } \\
\text { Palmita }\end{array}$ & 29 & 2 \\
\hline $\begin{array}{l}\text { Colorado de la } \\
\text { Mora }\end{array}$ & 13 & 7 \\
\hline $\begin{array}{ll}\text { Zapote } & \text { de } \\
\text { Picachos } & \end{array}$ & 17 & 6 \\
\hline Total & 66 & 16 \\
\hline Porcentaje & $80 \%$ & $20 \%$ \\
\hline
\end{tabular}

Table 10 Situational perception of the people surveyed in the towns under study

Source: Own elaboration with data from the survey

\section{Results: Analysis, observations and comments in the interviews}

Currently, the existence of work and the development of their traditional productive activities is different in terms of the form and products that the communities had originally generated; Agriculture and fishing is increasingly difficult, since two localities were relocated, making it difficult for them to cultivate the land, being moved to places where the land is not suitable for their traditional crops, to the hills, and consequently, when sowing, the same yields that were had in their previous fields of cultivation are not achieved.

To the above, the situation of food insecurity is added, a problem that is addressed by the UN (2012), when referring to indigenous peoples, since, in addition to being difficult access to food due to its absence and the distances to obtaining them aggravates the situation of the inhabitants of these communities, seeing high prices as a result of transportation costs, and the little monetary income they obtain is insufficient to access these goods; this, added to the lack of a culture or the predominance of a poorly diversified eating pattern, prevents them from obtaining the necessary nutrients.

Regarding fishing, an activity that was previously carried out freely and independently, in the communities under study, it is observed that today they have to be done in an organized way, in communal cooperatives, even to acquire financing and purchase instruments, catch, and addition to using modern fishing techniques. 
In the same way, a lack of regulations can be observed, which leads to an overexploitation of the fish "tilapia largemouth bass", for sale to the regional or external market, entire families are dedicated to catching this species, thereby causing a shortage of fish, same, even for family consumption, that is, scarce their priority staple food.

The aforementioned, expresses the situation raised by Damonte and Sandoval (2015 and 2017), in their study on the hydrosocial territory, who reflect on the correlation between social practices and water resources, as well as, in the production of specialties, where they are articulated productive and reproductive activities of the communities, water policy discourses, public and private intervention, as well as the different actors, for the appropriation, use and control of water and fisheries.

This perspective of analysis is observed in the localities under study, since, once the Aguamilpa hydroelectric dam was built, there were strong conflicts over the management and use of water resources, and the new forms of association, generating codes to be able to coexist, among the members of the communities affected by the dam (cited in Pelayo and Gazca, 2019).

Even though the document presents different concepts of poverty, it agrees with Sen's idea, in the sense that poverty is a complex and complicated world and, therefore, we understand that it is difficult to conceptualize, because no matter what It has been analyzed, there are contradictions and difficulties, both in its conceptualization and in the way of perceiving it, even by the same people who are in such a condition.

Even more difficult is the desire, not only to establish a specific set of variables for their measurement, but also parameters for their quantification and delimitation, that is, to determine how many people there are in one type of poverty, and when it is switched to another type, that is, from poverty to extreme poverty or vice versa, from extreme poverty to poverty, or to determine if having an " $x$ " deficiency is better or worse than having a deficiency " $y$ ", or if eliminating a group of deficiencies, solves the problem, life to who is conceptualized as poor.
In the case of this work, we worked with institutional concepts, specifically those of CONEVAL, which are what allow evaluating the results of government strategies to resolve the poverty situation in marginalized localities.

Similarly, we accept Brundland's (1999) assertion, in the sense that indigenous peoples are the ones with the greatest presence in the world of poverty, even more so, if they are compared with urban localities, since, Rural localities, and even more indigenous ones, are the ones that suffer, not only the lowest incomes, but also the ones with the least possibilities of having the goods and services that allow them a better standard of living.

When analyzing the information and addressing the dimensions considered in the field work, we found the following:

From a demographic perspective, of the 85 people identified through the survey, it was found that, in their homes there is a marked overcrowding situation, for the four analyzed localities, since men and women coexist, regardless of age or role who play at home, in addition, if they do not have the proper privacy that is required, for couples, children and young women, this is affirmed, because in the homes there is a minimum average of 4.79 people, although in Several of them, there are 5 or 6 people who share two or a maximum of three rooms, which although, are spacious, one of them serves as a living room, kitchen, dining room, and the other as a bedroom, and in some cases there is bathroom in the dwelling, or is constructed of wood and tile outside the main building.

Taking into account the Economic dimension, it is observed that, of the population identified in the study, part of them work in nontraditional productive activities, however, even when there are sources of employment and they are hired as employees, wages are quite precarious and they do not allow them to significantly improve their living conditions, in addition to lacking the coverage and benefits of social security. 
With regard to Income, it can be observed in the salary ranges, that the largest proportion of the population living in the localities under study have very low salary levels, which shows the high precariousness in which they live; $56 \%$ of the surveyed population stayed at the income level (a), with a maximum limit of $\$ 2,000.00$, and if it is considered that one or two work in a family greater than four members, with that data, it can be deduced that a person with that income level is in the extreme poverty line by income, because, according to CONEVAL, in the rural area, for the year 2018, said line was determined by an income of $\$$ $1,043.41$ pesos per person.

In addition, if the following considerations are taken into account: first, that the income range is between $\$ 400.00$ and $\$$ $2,000.00$ pesos per month, which does not mean that everyone obtains an income equal to the maximum, that is, $\$ 2000.00$; second, that this person is the breadwinner and is the only one who receives income; third, that each family has an average of 4.79 members; Then then, it would require at least $\$ 5,217.05$ pesos, so that both he and his family will not be located in this extreme poverty line by income, a situation that will hardly arise, because the woman works at home, and supports the husband, but only in the activities of his plot, the same happens in the case of minor children who depend on him, they only support him in his activities, without receiving income or receive less income than the father of the family.

In the case of people who were located in the second income range, whose maximum limit is $\$ 4000.00$ pesos, it is necessary that this was reached by $34 \%$ of the people, with the observation that this income, reaches to exceed The minimum wage, which for January 1, 2018, was $\$ 2,650.00$ pesos per month, however, as in the previous case, if only the respondent works and has the average number of members identified in the family, it would remain in the same situation of poverty, with which it can be seen that $90 \%$ of the population would be in a situation of extreme poverty due to income.
On the other hand, it is noteworthy that the wage differences between agriculture, fishing and industry can be summarized by saying that, while in the last activity, the processes can be continuous ( 8 hours a day, 360 days a year), in agriculture and fishing are seasonal (sowing or harvesting period, in agriculture and, in fishing, they would be intermittent periods of a few weeks or months).

In this sense, the period of agricultural or fishing use requires a temporary workforce throughout the year; Therefore, these workers are forced to supplement their income, as salaried workers or day laborers outside the plot, carrying out other activities to survive, or migrating during the rest of the year, since they do not work in their fishing or in its agricultural spaces.

In the personalized interviews, a coincidence with the above was found, in the sense that, not only is it difficult to improve the situation in which they live, but, on the contrary, it worsens, as they have employment difficulties, because:

"When we started there were few members of the cooperatives, but the children of the partners have been integrated and, every time we are more, and the reservoir is the same" also, that those who are employed are recruited by the same buyers of the product, who set their prices and, "do not allow the fisherman to divert part of their production to another market, under the threat of no longer buying them", which keeps them subject and, having no alternative for sale, they adhere to the conditions these people impose on them.

In addition, with the cultural change of work, the social place assigned to them and the meaning it has for people, they face a process of adaptation to new conditions of access to employment, and subjects it to greater vulnerability, in this market work, which is progressively individualized; Well, working people have to be increasingly versatile and have a great capacity for learning and adaptation, in order to maintain their income, as Barba (2004) points out. 
Regarding the Education dimension, it was found that there is a high percentage of illiterate people (42.35\%), and that, incorporating those with up to primary level, they add up to a total of $60 \%$ of the surveyed population, which expresses the high educational gap that prevails in the four localities; It should be noted that some parents make the effort so that their children can achieve higher educational levels, however, the conditions of poverty and mobility themselves reduce the opportunities and possibilities of achieving this objective, since young people are required for development productive activities that allow family sustenance, here it is worth mentioning that the town of Colorado de la Mora has its own satellite secondary school, while the other communities near the dam's curtain are concentrated in a School hostel, located in the community of Potrero de la Palmita, where they are given assistance and classes throughout the week, returning on the weekend (via boat) with their families, in the same way for the case of the study of the level secondary school, in the town of Aguamilpa and Zapote de Picachos, they have telesecundaria facilities.

In relation to housing conditions, in the four communities under study, it was found that these are not adequate for quality housing, with which there is another argument to point out the conditions of poverty, that is, the lack of quality homes; Since it was observed that the "cement" floor predominates, they call it that, because it is a mixture of sand, gravel, water and gray dust (cement), and once the composition of the mixture is made, they pour it into the earth giving it a level to make it more firm. This type of work is done by the same owners in most houses.

Regarding the roof of the houses of the people surveyed, the majority $(83 \%)$ are roofs made of asbestos sheet, cardboard and very few with cement material. Another issue that stands out is the walls of the houses, in which the material called "adobe" predominates, that is, they are made with mud and herbs or with horse excrement, combined with water, all of which are mixed and they are filling the walls with wood. Very few houses were made of block or brick.
In the case of relocated localities, such as Potrero de la palmita, a significant difference is noted in the construction of the houses, since, when supported by the Federal Electricity Commission, they were given material, with the commitment to move towards another part of the mountain and, to settle there. In Colorado de la Mora, being a relocated community, their houses were built, however, the houses according to the interviews with their residents; "They are very hot, which sometimes forces them to seek to sleep in hammocks outside the homes", since the builders did not consider the types of materials, or their height, to counteract the conditions that occur in the In addition to that, some families are overcrowded, due to the small number of rooms that comprise them.

Regarding food, it can be said that it adds to the deficiencies of the population, which are considered for the determination of poverty, since in the four localities, an average of $29 \%$ of the population only eats two meals a day, for more than $70 \%$ of the population, their diet is not adequate, nor is it diversified, and due to their poverty conditions, it is based on, and in some cases complemented, with what they obtain from their land, from hunting and fishing, They basically consume fish and beans, and meat and vegetables are scarcely consumed.

They pointed out that the very conditions of the land make it difficult to grow vegetables, and bringing them to the community fresh from the city of Tepic is expensive, so their consumption is low, or only canned vegetables are consumed; and they have the option of eating meat and fish, because they hunt for their own consumption, and in the case of fishing, the surplus obtained is sold to cooperatives from where they obtain extra income, for their family. Another important aspect to consider is that, in the Sierra de Nayarit, the prices of the products are high, since the cost of transporting them to the area implies the use of land transport to the reservoir of the dam, and from there, transfer them by boat to the communities; for this reason, respondents point out that income is insufficient to purchase these goods. 
Finally, it should be noted that for $80 \%$ of those surveyed, the perception of the current situation in their locality, with respect to the situation that prevailed before the construction of the dam, is better, in the sense that they have better working conditions life by counting services such as electricity and piped water, in addition to a job, a salary and an income, for a longer time

The situation indicated so far, coincides in the existence of the problems identified in an article on indigenous communities, published by the Economist (2018), in which it is highlighted that, of every 10 members of an indigenous community, 3 of them present educational backwardness, inability to feed themselves and poor quality of their homes, and that 2 out of 10 do not have access to health institutions.

\section{Acknowledgments}

For the development of the research project and of which this article is part, we are grateful to the Coordination of Indigenous Peoples (CDI), who provided us with the contacts of the community leaders and who will also present us to the communities so that we open to carry out interviews and surveys with the people who are part of the selected criteria, in the same way, to the group of students of the seventh semester of the Political Science Program, for supporting us in the interviews and information gathering, as well as their valuable comments on what was observed in the communities, finally, it is important to point out that the project participated in the call "University Productivity through Research", carried out with resources from the Special Tax of $12 \%$ destined to the Autonomous University of Nayarit 2017, thank the Board of Trustees of the Autonomous University of Nayarit for having been benefited with this resource to be able to travel to the communities and carry out interviews and surveys in the localities under study.

\section{Conclusions}

In synthesis, we can observe from the results of this work, that the construction of the Aguamilpa hydroelectric dam, in addition to implying profound social, economic and political changes, as well as disturbances to the nature of the communities, represented a territorial reorganization of the community and the manifestation of new forms of usurpation and territorial occupation, in addition, not only did it not solve the problems of the population of these localities, which was a political slogan of those who promoted and carried out its construction, but also has contributed to a process of pauperization in the study communities.

Consequently, it can be concluded that the programs of "Combat to poverty", such as the "National Crusade against hunger" that was proposed to attack poverty and hunger in marginalized and extremely poor localities, have worked very deficiently and, they have been more, as alleviating the conditions of poverty in the short term, than as true instruments of solution to the problems that afflict the communities, which does not favor the solution of the conditions of poverty, social backwardness and marginalization.

It should be noted that the people of these communities have been added to the market of large product companies, and it is common to find packaged and canned food, as well as bottled beverages, with what is seen as large companies, they have no limits in their expansion and incorporate into the markets of their processed products, (liquors, and other packaged products) and communications (cable television, cell phones), the communities, no matter how remote they may be, altering their traditions and ways of food and life.

It agrees with Barba (2004), in that social development and economic growth are not articulated in a satisfactory way, and the construction of more egalitarian and inclusive societies remains pending in the social agenda of the region, which implies differential challenges, depending on the type of wellness regime from where they are faced. 


\section{Recommendations}

Promote before the Governments of the three levels, the implementation, monitoring and constant evaluation of programs and strategies, aimed at improving the housing conditions of the communities in which it exists; lack of services, poor quality materials in the construction of the roof and floor, as well as overcrowding in the living spaces at home.

Promote, monitor and evaluate programs at different educational levels, both for young people and adults with educational backwardness, in the same way, develop planning so that the area could have institutions of secondary and higher technical education, which allow them to the residents, develop sustainable productive projects, taking advantage of social programs, and make adequate and efficient use of the natural resources available, in order to meet their essential and complementary needs, as well as to generate product and surpluses that they can commercialize, in the first instance in the region, without ruling out the possibility of, in the future, opening a market in the state capital.

Propose the analysis and evaluation of the social programs that operate, and whose purpose is to eliminate or reduce the conditions of poverty and extreme poverty, in order to avoid duplication and achieve greater equity in support.

\section{References}

Aranda García Luis V. (2020); Participación comunitaria del ejido colorado de la mora, en el contexto de la construcción de la presa Aguamilpa hacia el desarrollo local. T e s i s para obtener el grado de Maestro en Ciencias para el Desarrollo, Sustentabilidad y Turismo. UAN Tepic Nayarit.

Banco Interamericano de Desarrollo (15 julio de 2020). Sen Amartya y las mil caras de la pobreza (julio $1^{\circ}$. 2001). https://www.iadb.org/es/noticias/amartya-seny-las-mil-caras-de-la-pobreza
Barba, C. (2004). Régimen de bienestar y reforma social en México, CEPAL - SERIE Políticas sociales. recuperado junio 20 de 2020 en:

https://repositorio.cepal.org/bitstream/handle/11 362/6080/S047561_es.pdf?sequence=1\&isAllo wed $=\mathrm{y}$

Bazán, A., Quintero, L. y Hernández, L. (2011). Evolución del concepto de pobreza y el enfoque multidimensional para su estudio. Quivera Revista de Estudios Territoriales, 13 (1), 207-219. recuperado el 3 de Julio de 2020 en: https://www.redalyc.org/articulo.oa?id=401/ 40118420013

Cimadamore, D., Eversole, R. y McNeish, A. (2003). Pueblos indígenas y pobreza. Una introducción a los enfoques multidisciplinarios. Recuperado el día 31 de julio de 2020 en internet:

http://biblioteca.clacso.edu.ar/clacso/clacsocrop/20100620065831/pueblos.pdf

Consejo Nacional de Evaluación. (27 julio 2020) Informe de pobreza y evaluación en Nayarit. https://www.coneval.org.mx/coordinacion/entid ades/Documents/Informes_de_pobreza_y_evalu acion_2018_Documentos/Informe_Nayarit_201 8.pdf

Consejo Nacional de Evaluación (27 julio 2020). Medición de la pobreza. Glosario https://www.coneval.org.mx/Medicion/Paginas/ Glosario.aspx

Consejo Nacional de Población (27 julio 2020). Índices de marginación, www.conapo.gob.mx.

Cámara de Diputados (27 julio 2020). Constitución política de los Estados Unidos Mexicanos. Artículos $1^{\circ}, 2^{\circ}, 4^{\circ}, 5^{\circ}, 7^{\circ}, 9^{\circ}, 10^{\circ}, 11^{\circ}$ al $24^{\circ} \quad$ y $27^{\circ}$. http://www.diputados.gob.mx/LeyesBiblio/pdf_ mov/Constitucion_Politica.pdf

Deleeck, K. y De Lathouwer, L. (1992). Poverty and the adequacy of social security in the EC (Aldershot: Avebury). Recuperado 10 de junio de 2020 en https://journals.sagepub.com/doi/abs/10.1177/0 95892879500500207 
Foro-México. (27 de julio de 2020). http://www.foro-mexico.com/nayarit/coloradode-la-mora/mensaje-220574.html;

García, A. K. (16 septiembre de 2018). 7 de cada 10 indígenas en México son pobres. $E l$ economista.https://www.eleconomista.com.mx/ economia/7-de-cada-10-indigenas-en-Mexicoson-pobres-20180916-0007.html,

Hernández, F., González, V. M., Ibarra, L.S y del Real, J.H. (2018). Vulnerabilidad social de los pueblos ribereños de la presa hidroeléctrica de Aguamilpa en el estado de Nayarit. Edit. Academia Journal. Elibro on line 9781939982346.

Hernández, F., González, V M., Ibarra, L. S y del Real, J.H. (2017). Evaluación socioeconómica de los pueblos ribereños de las presas hidroeléctricas de Nayarit a partir de un análisis estadístico multivariante de clúster. Edit. ECORFAN. Elibro on line 978-1-939982-32-2

Manzanares R. José L. (2013). Programas sociales: transferencias públicas y privadas en México, Economía: teoría y práctica - Nueva Época, número 39, julio-diciembre 2013 http://www.scielo.org.mx/pdf/etp/n39/n39a4.pd $\mathrm{f}$

Mi pueblo. (27 de julio de 2020). http://www.mipueblo.mx/18/1304/zapote-depicachos-la-mesa/

Morret, J. (2001). Los indígenas, hijos bastardos del régimen. Encuentro, gobierno y sociedad. Revista de la Dirección General de Desarrollo Político del Gobierno del estado de México, año2 no.3 segunda época: 107-116. NuestroMéxico. (27 de julio de 2020). http://www.nuestro-mexico.com/Nayarit/DelNayar/Areas-de-menos-de-500-

habitantes/Aguamilpa/Nuestro-México. (27 de julio de 2020). http://www.nuestromexico.com/Nayarit/Del-Nayar/Areas-demenos-de-500-habitantes/Potrero-de-laPalmita/

Organización de la Naciones Unidas. (12 de junio 2012). Panorama de las seguridad alimentaria y nutrición en América latina y el Caribe.

http://www.fao.org/americas/publicacionesaudio-video/panorama/2019/es/
O’Higgins, M. y Jenkins, S. (1990). "Poverty in the European Community" en Teekens, R. y Van Praag, B. (eds.) Analysing poverty in the European Community, Eurostat News Special Edition (Luxemburgo: European Communities). Pueblos América. (27 de julio de 2020). http://mexico.pueblosamerica.com/i/aguamilpa/

Sen, A. (1992). Sobre conceptos y medidas de pobreza, 13 páginas Año Publicación: 1992 Revista: Comercio Exterior, vol. 42. núm. 4 Link: http://tinyurl.com/ycrlaoh

Spicker, P., Alvarez, S. y Gordon, D. (2009). Definiciones de pobreza: doce grupos de significados.http://biblioteca.clacso.edu.ar/gsdl/ collect/clacso/index/assoc/D9376.dir/06spicker. pdf

Secretaría de Desarrollo Social (10 junio de 2020). GUÍA DE programas sociales 2015.http://www.sedesol.gob.mx/work/models/ SEDESOL/images/guias/Guia_de_Programas_ Sociales_2015.pdf

Secretaria de Desarrollo Social (27 de julio de 2020). Catálogo de localidades. Sistema de apoyo para la planeación PDZP. http://www.microrregiones.gob.mx/catloc/Locd eMun. asp $x$ ?buscar $=1 \&$ tipo $=$ nombre $\&$ campo $=10$ c\&valor $=$ colorado $\% 20 \mathrm{de} \% 20 \mathrm{a} \% 20$ mora\&ent $=\mathrm{a}$ guamilpa\&mun=

Survey Mokey Calculator. (2 de julio de 2017). https://es.surveymonkey.com/mp/sample-sizecalculator/

Secretaria del Trabajo y Previsión Social (10 de junio de 2020). Comisión Nacional de Salaros Mínimos.https://www.gob.mx/cms/uploads/atta chment/file/285013/TablaSalariosMinimos01ene2018.pdf 